\title{
СИНТЕЗ, АНТИАГРЕГАНТНАЯ \\ И АНТИТРОМБОТИЧЕСКАЯ АКТИВНОСТЬ С(4) \\ ЗАМЕЩЕННЫХ ПИРОГЛУТАМИНОВЫХ КИСЛОТ
}

\author{
А.Ю. Вигоров', И.А. Низова', Г.Л. Левит , Д.А. Бакулин², О.И. Назаров², \\ И.Н. Тюренков², В.П. Краснов' \\ ${ }^{1}$ Институт органического синтеза им. И.Я. Постовского УрО РАН, \\ 620108 , Россия, г. Екатеринбург, ул. С. Ковалевской, д. 22/20. \\ ${ }^{2}$ Кафедра фармакологии и фармации Института НМФО, \\ ВолгГМУ, 400131, Россия, г. Волгоград, пл. Павших Борцов, д. 1.
}

DOI: 10.19163/MedChemRussia2021-2021-42

E-mail:vigorov@ios.uran.ru

Производные пироглутаминовой кислоты обладают разнообразной биологической активностью, в том числе антиагрегантным действием, что делает перспективным исследование их антиагрегантных и антитромботических свойств.

Целью работы был синтез новых производных 4-аминопироглутаминовой кислоты и изучение их антиагрегантной и антитромботической активности.

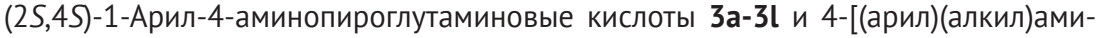
но]пироглутаминовые кислоты 5a,b получалипутем нуклеофильного замещения

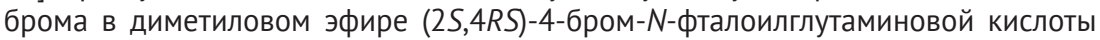
(1) ароматическими аминами с последующей кристаллизацией для выделения (2S,4S)-диастереомера и удалением защитных групп.

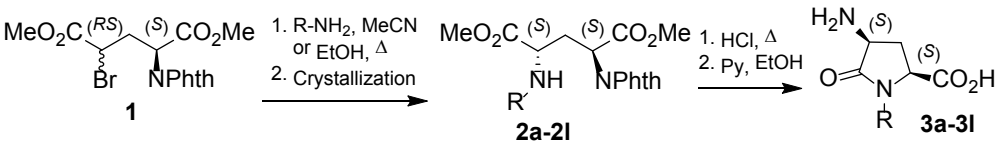

$$
\begin{aligned}
& \mathrm{R}=\mathrm{Ph}(\mathbf{2 a}, \mathbf{3 a}), 4-\mathrm{FC}_{6} \mathrm{H}_{4}(\mathbf{2 b}, \mathbf{3 b}), 4-\mathrm{ClC}_{6} \mathrm{H}_{4}(\mathbf{2 c}, \mathbf{3 c}), 4-\mathrm{BrC}_{6} \mathrm{H}_{4}(\mathbf{2 d}, 3 \mathbf{d}), 4-\mathrm{HOC}_{6} \mathrm{H}_{4}(\mathbf{2 e}, \mathbf{3 e}) \text {, }
\end{aligned}
$$

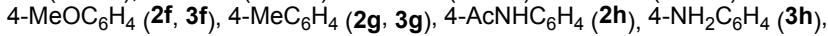

$$
\begin{aligned}
& \left.3-\mathrm{FC}_{6} \mathrm{H}_{4}(\mathbf{2 i}, \mathbf{3 i}), 3-\mathrm{BrC}_{6} \mathrm{H}_{4} \mathbf{( 2 \mathbf { j }}, \mathbf{3} \mathbf{j}\right), 3-\mathrm{HOC}_{6} \mathrm{H}_{4}(\mathbf{2 k}, \mathbf{3 k}), 3-\mathrm{MeC}_{6} \mathrm{H}_{4}(\mathbf{2} \mathbf{l}, \mathbf{3} \mathbf{l})
\end{aligned}
$$
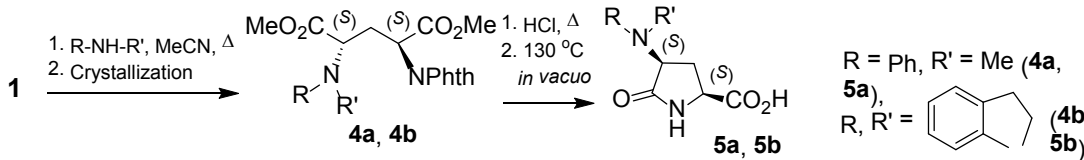

Изучение антиагрегантной и антитромоботической активности показало, что ряд синтезированных соединений ингибируют агрегацию тромбоцитов invitro (богатая тромбоцитами плазма крыс) и invivo (крысы). Соединения 3b и 3h замедляют процесс тромбообразования на модели артериального и венозного тромбоза (на уровне ацетилсалициловой кислоты), не оказывая влияния на параметры плазменного гемостаза. Исследованные соединения обладают малой токсичностью (LD 50 >3000 мг/кг, мыши).

Работа выполнена при финансовой поддержке РФФИ, проект № 20-43-660045 p_a. 